\title{
Perbandingan Jenis dan Jumlah Echinodermata Di Perairan Pantai Krakal Gunung Kidul Yogyakarta Dan Pantai Pailus Jepara, Jawa Tengah
}

\author{
Ardita Elok Mahendra Putri*, Sunaryo, Hadi Endrawati \\ Departemen IImu Kelautan, Fakultas Perikanan dan IImu Kelautan, Universitas Diponegoro \\ Jl. Prof.H.Soedarto S.H, Tembalang,Semarang, Jawa Tengah 50275 Indonesia \\ ${ }^{*}$ Corresponding author, e-mail : ardita.elokmp@gmail.com
}

\begin{abstract}
ABSTRAK : Echinodermata merupakan biota yang dapat ditemukan hampir di semua ekosistem laut. Echinodermata cukup melimpah keberadaannya di kawasan terumbu karang, hal ini karena terumbu karang berperan sebagai tempat berlindung dan mencari makan bagi Echinodermata. Dalam rantai makanan, Echinodermata memiliki peranan sebagai pemakan seston atau detritus, dan merombak sisa bahan organik. Echinodermata juga berperan sebagai bioindikator parameter kualitas perairan. Penelitian ini bertujuan untuk mengetahui kelimpahan Echinodermata yang terdapat di Pantai Krakal, Gunung Kidul, Yogyakarta dan Pantai Pailus, Jepara, Jawa Tengah. Metode yang digunakan dalam penelitian ini yaitu metode deskriptif. Pengambilan sampel pada penelitian ini menggunakan metode transek kuadran dengan ukuran $1 \times 1 \mathrm{~m}$. Hasil pengamatan di Pantai Krakal ditemukan 2 kelas dari filum Echinodermata, antara lain 3 species dari Kelas Ophiuroidea yaitu Ophiocoma erinaceus, Ophiocoma scolopendrina, Ophiarachna affinis, dan 3 species dari Kelas Echinoidea yaitu Echinometra viridis, Echinometra oblonga, dan Stomopneustes variolaris. Sedangkan jenis Echinodermata yang ditemukan di Pantai Pailus ditemukan 1 Kelas Echinodermata yaitu Holothuridea yang terdiri dari 3 spesies, yaitu Holothuria atra, Holothuria scabra, dan Holothuria leucospilota. Hasil penelitian menunjukkan kelimpahan individu tertinggi penelitian di Pantai Krakal adalah Ophiocoma scolopendrina $\left(7,05 \mathrm{ind} / \mathrm{m}^{2}\right)$,sedangkan kelimpahan individu tertinggi di Pantai Pailus adalah Holothuria scabra (2,13 ind $\left./ \mathrm{m}^{2}\right)$.
\end{abstract}

Kata Kunci : Holothuria atra, Kelimpahan, Krakal, Pailus

\section{The Comparation Species and Number of Echinoderms in the Waters of Krakal Beach, Gunung Kidul, Yogyakarta and Pailus Beach, Jepara, Central Java}

\begin{abstract}
Echinodermata is a biota that can be found almost in all marine ecosystems. Echinodermata quite abundant presence in the area coral reefs, because it serves as shelter and feed for Echinodermata. In the food chain, Echinodermata has a role as a seston eater or dentrite, and remodel the rest of the organic material. Echinodermata also serves as a bioindicator of water quality parameters. This study aims to determine the abundance of Echinodermata found in Krakal Beach, Gunung Kidul, Yogyakarta and Pailus Beach, Jepara, Central Java. The method used in this research was descriptive method. Sampling in this research used quadrant transect method with size $1 \times 1 \mathrm{~m}$. The results of observation on Krakal Beach found 2 classes of Echinodermata phylum, among others 3 species of Ophiuroidea namely Ophiocoma erinaceus, Ophiocoma scolopendrina, Ophiarachna affinis, and 3 species of Echinoidea is Echinometra viridis, Echinometra oblonga, and Stomopneustes variolaris. While the type of Echinodermata found in Pailus Beach found 1 Class Echinodermata is Holothuridea consisting of 3 species, namely Holothuria atra, Holothuria scabra, and Holothuria leucospilota. The results showed the highest individual abundance of research on Krakal Beach was Ophiocoma scolopendrina $\left(7,05 \mathrm{ind} / \mathrm{m}^{2}\right)$, while the highest individual abundance in Pailus Beach was Holothuria scabra $\left(2,13 \mathrm{ind} / \mathrm{m}^{2}\right)$.
\end{abstract}

Keywords: Abundance, Holothuria atra, Krakal, Pailus

\section{PENDAHULUAN}

Echinodermata merupakan salah satu hewan yang sangat penting dalam ekosistem laut dan bermanfaat sebagai salah satu komponen dalam rantai makanan. Dalam rantai makanan, 
Echinodermata berperan sebagai pemakan sampah organik/detritus dan hewan kecil lainnya. Dengan demikian, organisme ini mempunyai peran sebagai pembersih lingkungan laut terutama pantai. Selain itu echinodermata juga dapat dijadikan parameter (bioindikator) kualitas di perairan laut (ekosistem laut). Dahuri (2003) menyatakan bahwa jenis-jenis Echinodermata dapat bersifat pemakan seston atau pemakan detritus, sehingga peranannya dalam suatu ekosistem untuk merombak sisa-sisa bahan organik yang tidak terpakai oleh spesies lain.

Wilayah perairan pantai merupakan wilayah perairan laut yang masih terjangkau oleh pengaruh daratan. Perairan ini memiliki peranan sebagai sumberdaya hayati laut dan terdapat berbagai ekosistem di dalamnya. Ekosistem-ekosistem pantai utama yang banyak dibicarakan dan diteliti karena peranannya baik secara langsung maupun tidak langsung adalah terumbu karang, mangrove, dan lamun (Romimohtarto dan Juwana, 2007).

Bird \& Ongkosongo (1980) menyatakan bahwa di Pulau Jawa, kawasan pesisir utara Pulau Jawa berhadapan dengan perairan yang memiliki kondisi energi gelombang yang rendah dari Laut Jawa, sementara kawasan pesisir selatan berhadapan dengan perairan berenergi gelombang yang kuat karena swell yang datang dari Samudera Hindia. Perbedaan kondisi energi gelombang di perairan pesisir Pulau Jawa tercermin pada perbedaan kondisi geomorfologi pesisir antara kawasan pesisir utara dan pesisir selatan pulau tersebut. Daratan pesisir bagian utara Pulau Jawa merupakan dataran rendah dengan banyak delta. Semua delta di Pulau Jawa terdapat di kawasan pesisir bagian utara. Sementara itu, kawasan pesisir selatan Pulau Jawa didominasi oleh pantai curam dan bertebing dengan selingan pantai pasir.

Pantai Krakal di Kabupaten Gunung Kidul, Yogyakarta memiliki karakteristik perairan yang sangat jernih dan ombak yang besar sehingga mengurangi pengendapan sedimen. Pantai ini didominasi batuan dan karang mati dengan tingkat kemiringan wilayah pasang surut relatif rendah. Daerah ini akan terendam air laut pada waktu air pasang dan akan menjadi daerah terbuka pada saat air laut surut. Kondisi ini menjadikan wilayah tersebut sebagai tempat yang paling mudah untuk dieksploitasi.

Pantai Pailus terletak di Desa Karanggondang, Kecamatan Mlonggo, Kabupaten Jepara, Jawa Tengah. Pantai Pailus terletak di sisi Utara Pulau Jawa dan berbatasan dengan Laut Jawa. Pantai Pailus memiliki karakteristik pantai yang landai dan ombak yang relatif kecil. Pantai Pailus merupakan pantai dengan substrat pasir berlumpur dan masih ditemukan banyak karang hidup.

Perairan pantai pada Pantai Krakal dan Pantai Pailus dimanfaatkan para wisatawan sebagai aktivitas wisata, dengan demikian menunjukkan tingginya aktivitas manusia di kedua pantai tersebut. Kedua lokasi kajian memiliki kondisi topografi yang berbeda, Pantai Krakal merupakan daerah rataan terumbu karang, sedangkan Pantai Pailus merupakan pantai dengan substrat pasir. Perbedaan topografi dan parameter lingkungan seperti temperatur, salinitas, $\mathrm{pH}$, air dan $\mathrm{D} . \mathrm{O}$ pada Pantai Krakal dan Pantai Pailus serta adanya aktivitas wisatawan akan mempengaruhi kelimpahan, jenis dan keanekaragaman Echinodermata yang ada di lokasi kajian.

\section{MATERI DAN METODE}

Materi penelitian yang digunakan adalah organisme dari Filum Echinodermata yang ditemukan pada lokasi penelitian Pantai Krakal, Gunung Kidul, Yogyakarta (gambar 1) dan Pantai Pailus, Jepara, Jawa Tengah (Gambar 2). Metode yang digunakan dalam penelitian ini adalah metode deskriptif. Metode deskriptif, yaitu metode penelitian yang digunakan untuk mengetahui variabel yang akan diteliti berdasarkan hasil penelitian di lapangan tanpa dihubungkan dengan variabel lainnya (variabel tersebut bersifat mandiri).

Penentuan lokasi penelitian dilakukan secara purpossive sampling method atau metode pengambilan sampel dengan perbandingan tertentu yaitu dengan cara mempertimbangkan faktor lingkungan yang berpengaruh terhadap materi penelitian di masing-masing lokasi sampling. Penelitian ini dilaksanakan pada tanggal 11 Mei 2018 di Pantai Pailus, Jepara, Jawa Tengah dan pada tanggal 12 Mei 2018 di Pantai Krakal, Gunung Kidul, Yogyakarta. Pengambilan data dan sampel pada penelitian ini menggunakan metode transek kuadrat dengan ukuran $1 \times 1$ meter (Yusron, 2010). 

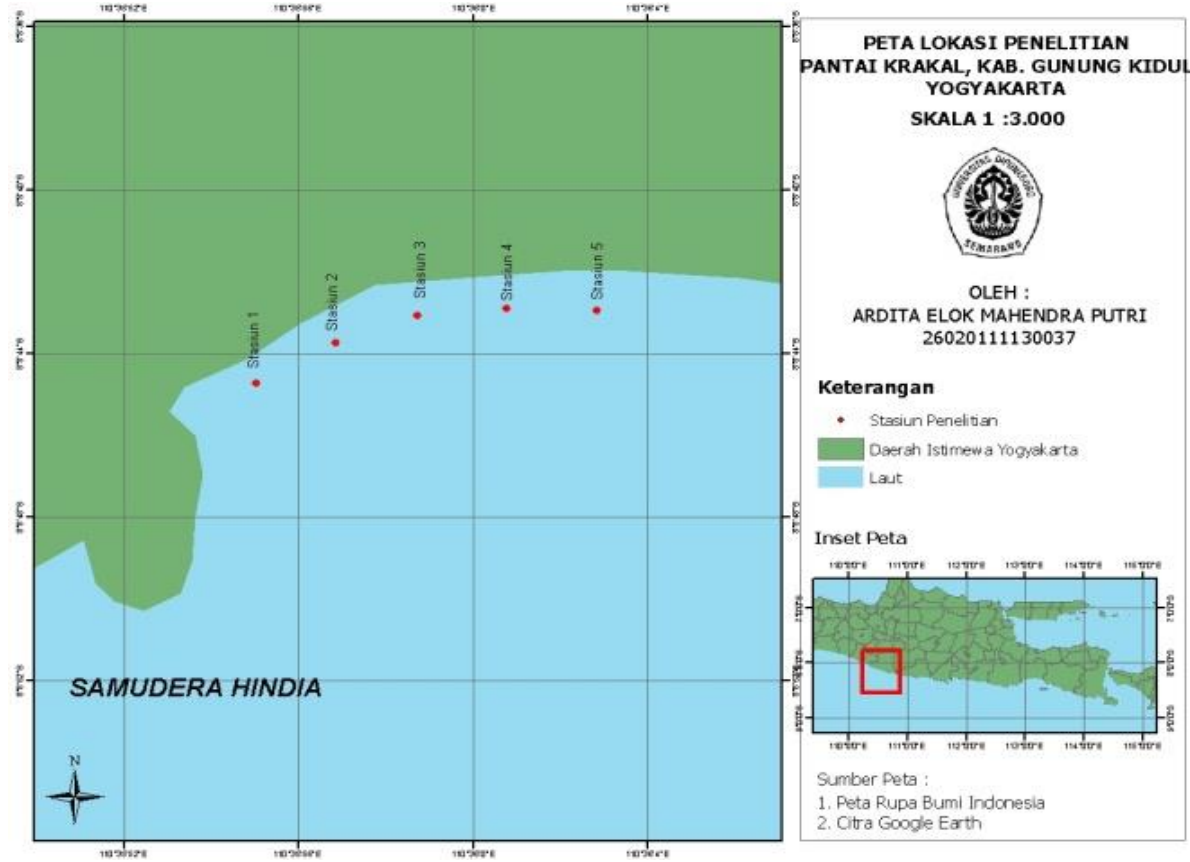

Gambar 1. Peta lokasi penelitian Pantai Krakal

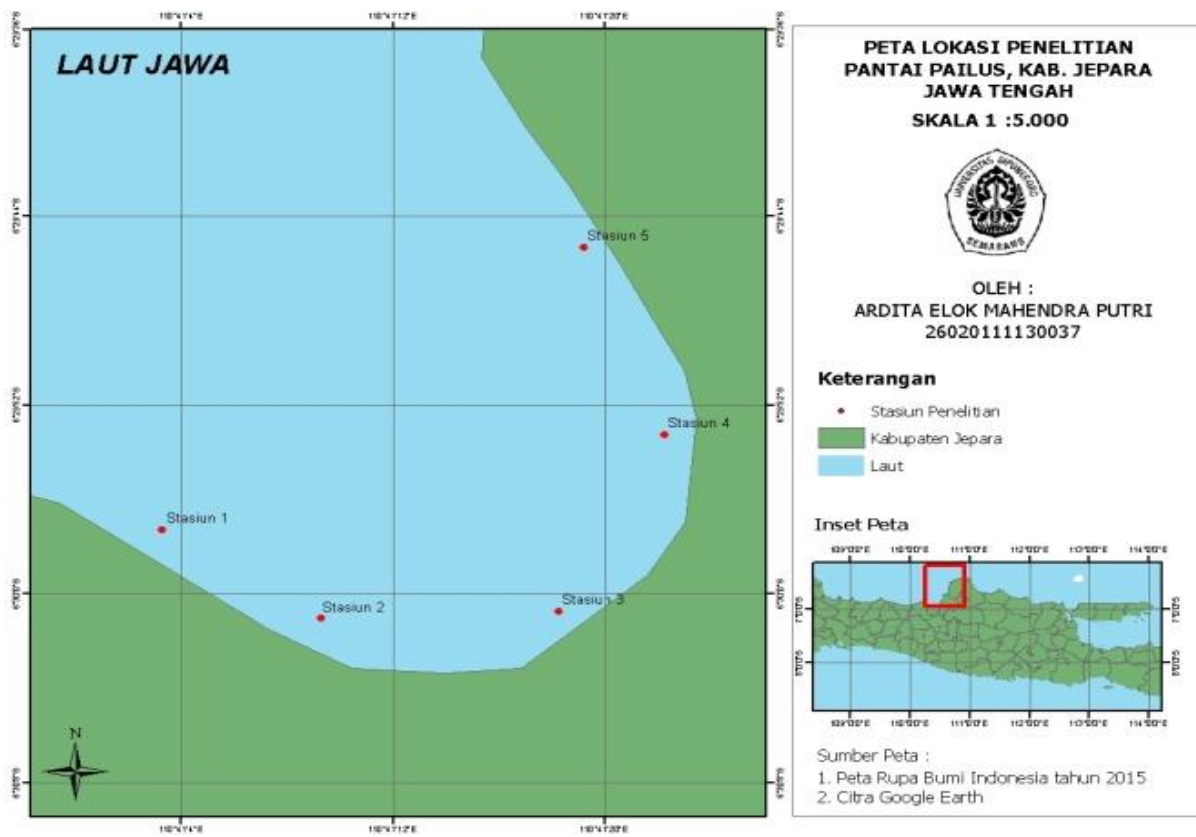

Gambar 2. Peta lokasi penelitian Pantai Pailus

Pengambilan sampel pada masing-masing lokasi dilakukan pada saat surut terendah dengan menarik garis transek dengan panjang transek masing-masing 110 meter ke arah laut. Transek kuadran yang berbentuk $1 \times 1$ meter dengan 16 subkuadran berukuran $25 \times 25 \mathrm{~cm}$ (English et al., 1994).

Roll meter (line transek) ditarik tegak lurus dari garis pantai ke arah laut sepanjang 110 meter pada saat air laut surut atau menjelang surut terendah, dengan $3 x$ titik pengamatan dalam setiap stasiunnya (titik ke 1: 0-10 m; titik ke $2: 50-60 \mathrm{~m}$; titik ke $3: 100-110 \mathrm{~m}$ ) dengan jarak antar stasiun penelitian adalah 20 meter (Gambar 3). Penentuan titik ini berdasarkan kedalaman perairan saat pasang surut dan diduga telah memiliki kondisi fisik ataupun biologis yang berbeda. Identifikasi sampel dilakukan dengan cara mengamati ciri-ciri morfologi secara langsung. 


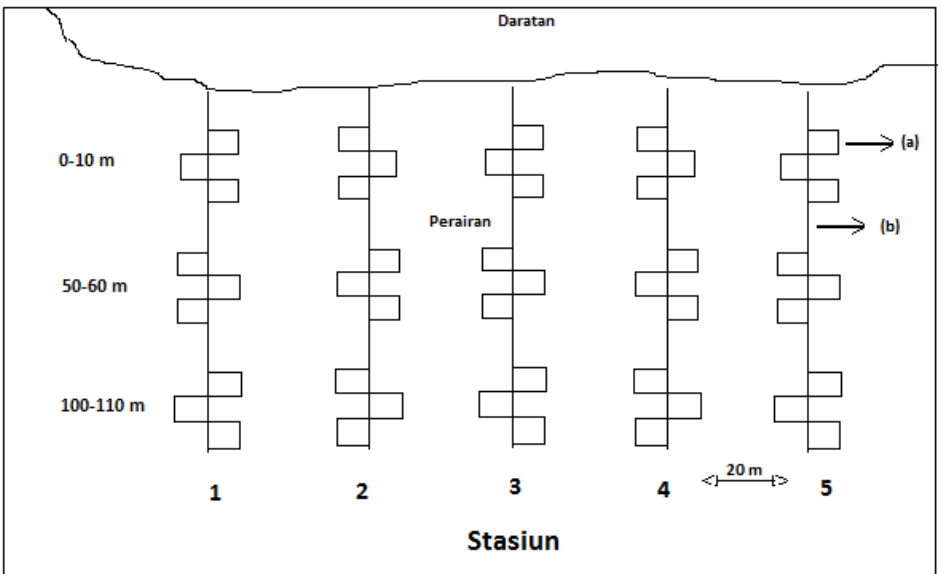

Gambar 3. Skematik Penempatan Transek Penelitian; (a) transek kuadran 1x1m; (b) line transek.

Frekuensi kehadiran merupakan nilai yang menyatakan jumlah kehadiran suatu spesies di dalam titik contoh yang diamati. Frekuensi kehadiran dapat dihitung dengan rumus Krebs (1985) sebagai berikut :

$$
\mathrm{FK}=\frac{\text { Jumlah plot yang ditempati suatu jenis }}{\text { Jumlah total plot }} \times 100 \%
$$

Keterangan : FK : 0-25 \% : Sangat jarang; 25-50\% : Jarang; 50-70\% : Sering; > 70\% : Sangat sering

Kelimpahan jenis pada setiap stasiun dapat dihitung dengan menggunakan rumus Odum (1971) sebagai berikut :

$$
\mathrm{Di}=\frac{n i}{\mathrm{~A}}
$$

Keterangan : Di : Kelimpahan jenis (ind $/ \mathrm{m}^{2}$ ); $n i$ : Jumlah total individu jenis (ind); A : Luas daerah yang disampling $\left(\mathrm{m}^{2}\right)$

Kelimpahan relatif adalah perbandingan antara jumlah individu jenis dan jumlah total individu seluruh jenis (Odum, 1971) :

$$
\mathrm{RDi}=\frac{n i}{\sum \mathrm{n}} \times 100 \%
$$

Keterangan : RDi : Kelimpahan relative; $n i$ : Jumlah total jenis i (ind); $\sum \mathrm{n}:$ Jumlah total individu seluruh jenis

Keanekaragaman dapat ditentukan berdasarkan indeks keanekaragaman (Shannon Wiener, 1963). Indeks keseragaman digunakan untuk mengetahui seberapa besar kesamaan penyebaran jumlah individu tiap jenis Echinodermata, yaitu dengan cara membandingkan indeks keanekaragaman dengan nilai maksimumnya, dengan rumus Indeks Equabilitas (E'), Fachrul (2007). Indeks Dominansi digunakan untuk mengetahui apakah suatu spesies mendominansi, dapat ditentukan dengan dengan rumus (Odum, 1971). Indeks kesamaan komunitas (Odum, 1993). Keterangan : $a$ : jumlah jenis pada stasiun 1 ; $b$ : jumlah jenis pada stasiun 2 ; $c$ : jumlah jenis yang sama pada stasiun 1 dan 2

\section{Pola sebaran}

Pola sebaran Echinodermata ditentukan dengan menghitung indeks dispersi morisita dengan persamaan: 


$$
I \mathrm{~d}=n \frac{\left(\sum \mathrm{X}^{2}-\mathrm{N}\right)}{\mathrm{N}(\mathrm{N}-1)}
$$

Keterangan : Id : Indeks disperse Morisita; $n$ : Jumlah plot pengambilan contoh; $N$ : Jumlah individu dalam $n$ plot.

Pola dispersi ditentukan dengan menggunakan kriteria sebagai berikut : $\mathbf{l d}<1$ : Pola dispersi seragam (Uniform); Id = 1 : Pola dispersi acak (Random); Id $>1$ : Pola dispersi mengelompok (Clumped)

\section{HASIL DAN PEMBAHASAN}

Hasil penelitian menunjukkan terdapat 3 kelas Echinodermata dengan 9 species yang ditemukan. Di Pantai Krakal ditemukan 2 kelas Echinodermata yaitu Ophiuroidea dengan 3 spesies, yaitu Ophiocoma erinaceus, Ophiocoma scolopendrina, Ophiarachna affinis, dan dari kelas Echinoidea yaitu Echinometra viridis, Echinometra oblonga, dan Stomopneustes variolaris. Sedangkan jenis Echinodermata yang ditemukan di Pantai Pailus dari kelas Holothuridea dengan 3 spesies, yaitu Holothuria atra, Holothuria scabra, dan Holothuria leucospilota.

Hasil pengamatan menunjukan spesies yang paling banyak ditemukan di Pantai Krakal adalah spesies 0 . scolopendina sebesar $7,05 \mathrm{ind} / \mathrm{m}^{2}$ jenis yang paling sedikit ditemukan yaitu jenis Stomopneustes variolaris sebesar $0,6 \mathrm{ind} / \mathrm{m}^{2}$. Spesies yang paling banyak ditemukan di Pantai Pailus selama pengamatan adalah $H$. scabra sebesar $2,13 \mathrm{ind} / \mathrm{m}^{2}$, selanjutnya $H$. leucospilota sebesar $2,09 \mathrm{ind} / \mathrm{m}^{2}$, dan yang paling sedikit ditemukan adalah $H$. atra sebesar $1,67 \mathrm{ind} / \mathrm{m}^{2}$ (Gambar 5).

Kelimpahan Jenis Echinodermata di Pantai Krakal lebih dominan pada Kelas Ophiuroidea sedangkan di Pantai Pailus dominan pada Kelas Holothuridea. Perbedaan jenis Echinodermata di perairan disebabkan beberapa faktor yaitu faktor biologi, fisika, kimia, geologi, dan aktivitas manusia. Salah satu faktor mencolok yang menjadi pembeda dari Pantai Krakal dan Pantai Pailus adalah jenis substrat.

Menurut Darsono (2007) Holothuridea dapat hidup di beberapa habitat yaitu terumbu karang, padang lamun dan makro alga serta substrat batu dan pasir karena digunakan tempat perlindungan dirinya, selain itu, Holothuridea menempati habitat yang selalu tergenang air bahkan saat surut, dan untuk hidupnya, hewan ini lebih menyukai habitat perairan jernih dan relatif tenang (Aziz, 1996).

Kondisi substrat pada Pantai Krakal yang terdiri dari beting karang tidak memungkinkan bagi Holothuria untuk melindungi diri, selain itu, dalam keadaan surut, daerah pantai pada Pantai Krakal tidak tergenang air sehingga tidak memenuhi kelayakan habitat bagi Holothuridea. Ophiuroidea dan Echinoidea merupakan Kelas dari Echinodermata yang memiliki kecenderungan untuk melekat pada karang, menurut Sugiarto dan Supardi (1995).

Ophiocoma scolopendrina berwarna kecoklatan. Cakram dorsal memiliki warna yang seragam yaitu hitam kecoklatan dan memiliki pola yang bervariasi. Cakram ventral memiliki warna yang lebih terang dan bervariasi. Ophiocoma affinis memiliki warna dasar krem dan terdapat duri pada lengan biasanya berwarna putih dan abu-abu yang memanjang sampai duri pada ventral. Panjang lengan mencapai $9 \mathrm{~cm}$ dan diameter cakram $2,5 \mathrm{~cm}$. Corak pada lengan berwarna krem dan abu-abu disertai dengan garis berwarna gelap dan merupakan hewan bentik (Sloan et al., 1979). Ophiocoma erinaceus pada permukaan dorsal tubuh berwarna hitam. Disk dorsal bergranula bulat yang menutupi seluruh permukaan. Permukaan ventral tubuh berwarna putih kekuningan. Ciri khas dari Spesies Ophiuroidea ini adalah memiliki garis berseling hitam putih pada dorsal arm plate. Memiliki warna hitam dan beberapa warna putih di sekitar lengan ventral. Panjang lengan mencapai $10 \mathrm{~cm}$. Spine memanjang dan berujung tumpul (Müller dan Troschel, 1842). Memiliki duri yang tebal dan pendek.

Echinometra viridis berbentuk ellips dan berwarna merah kecoklatan dan warna tubuh biasanya merah (maroon) dan memiliki ukuran $5 \mathrm{~cm}$ dan panjang duri $3 \mathrm{~cm}$. Biasanya duri berwarna coklat terang sedikit merah. Duri E. viridis pendek dan tebal, dengan titik-titik tajam (Kluijver et al., 2016). Diameter $5-20 \mathrm{~cm}$ dan panjang duri sekitar $3 \mathrm{~cm}$. Tubuhnya membulat oval, berwarna hitam duri berwarna cokelat terang sedikit merah. Duri tidak terlalu panjang, berduri tebal 
runcing dan jaraknya rapat-rapat. Echinometra oblonga memiliki warna cangkang gelap dan panjang diameter 5-20 cm. Berwarna hitam agak kecoklatan, berbentuk bulat oval. Duri-durinya sangat kuat namun sangat tumpul dan pendek dan panjang duri dapat mencapai $2,5 \mathrm{~cm}$.

Stomopneustes variolaris memiliki duri yang panjang serta tajam runcing yang memiliki panjang antara 2-4 cm. Duri berwarna hitam kecoklatan, atau hitam kehijauan jika terkena sinar matahari. Permukaan duri kasar dan beralur. Diameter horizontal rangka dewasa $70-80 \mathrm{~mm}$. $S$. variolaris yang ditemukan berwarna hitam, cangkang memiliki warna dasar hitam gelap. Berbentuk oval.

Holothuria atra memiliki corak warna hitam pekat yang menyelimuti keseluruhan tubuhnya sehingga menyulitkan untuk membedakan bagian dorsal dan ventralnya, namun pada bagian ventral biasanya terdapat warna kemerahan yang membentuk garis lurus dari ujung anterior hingga posterior. Integumentum pada teripang ini terasa kasar karena terdapat papila (tonjolantonjolan kecil pada dermis) yang menyelimuti tubuhnya (Feryanto dkk, 2015). Holothuria scabra atau sering disebut dengan teripang pasir memiliki bentuk badannya bulat panjang. Di bagian perut umumnya berwarna kuning keputih-putihan. Punggungnya berwarna abu-abu sampai kehitaman, dengan garis-garis melintang berwarna hitam. Seluruh bagian tubuh bila diraba terasa kasar.

Holothuria leucospilota berbentuk menyerupai silinder, lonjong menjelang akhir posterior. Pada akhir anterior, ada dua puluh tentakel lisan dengan tips bercabang dan mengelilingi mulut yang berada di sisi bawah tubuh. Hewan ini lembut dan lentur dan ditutupi dengan berdaging papila . Warna biasa adalah abu-abu arang atau kemerahan-hitam dengan abuabu pucat kaki tabung di bagian bawah tetapi pada lepas pantai Afrika ditemukan berwarna terang atau coklat gelap dengan bercak putih yang lebih besar menjelang akhir posterior.

Tabel 1. Species Echinodermata yang ditemukan di Pantai Krakal, Gunung Kidul, Yogyakarta dan Pantai Pailus, Jepara, Jawa Tengah

\begin{tabular}{|c|c|c|c|c|}
\hline Kelas & Ordo & Famili & Genus & Spesies \\
\hline \multicolumn{5}{|l|}{ Pantai Krakal } \\
\hline Ophiuroidea & Ophiurida & Ophiocomidae & Ophiocoma & $\begin{array}{l}\text { O. scolopendrina } \\
\text { O. erinaceus }\end{array}$ \\
\hline & & Ophiarachna & Ophiarachna & O. affinis \\
\hline Echinoidea & Camarodonta & Echinometridae & Echinometra & $\begin{array}{l}\text { E. viridis } \\
\text { E. oblonga }\end{array}$ \\
\hline & Stomopneustoida & Stomopneustidae & Stomopneustes & S. variolaris \\
\hline \multicolumn{5}{|l|}{ Pantai Pailus } \\
\hline Holothuridea & Aspidochirotida & Holothuridae & Holothuria & $\begin{array}{l}\text { H. atra } \\
\text { H. scabra } \\
\text { H. leucospilota }\end{array}$ \\
\hline
\end{tabular}

H. leucospilota (teripang getah) mempunyai kebiasaan berpegang pada batu karang mati, terutama bagian posteriornya, sedangkan bagian anteriornya sering menjulur pada permukaan pasir. Teripang ini bila disentuh akan mengeluarkan getahnya, seluruh permukaan tubuhnya berwarna hitam dan ditumbuhi oleh bintil-bintil/papilae halus (Aziz 1996).

Hasil penelitian menunjukkan Echinodermata yang paling banyak ditemukan di Pantai Krakal yaitu spesies dari Kelas Ophiuroidea yaitu Spesies O. scolopendina sebesar 7,05 ind $/ \mathrm{m}^{2}$ dan spesies yang paling sedikit ditemukan yaitu Spesies $S$. variolaris sebesar 0,6 ind $/ \mathrm{m}^{2}$. Tidak ditemukan Kelas Holothuridea seperti pada Pantai Pailus, Jepara, Jawa Tengah di Pantai Krakal.

Hasil pengamatan yang dilakukan di Pantai Pailus pada tanggal 11 Mei 2018 di 5 stasiun, diperoleh 1 Kelas dari Echinodermata yaitu Kelas Holothuridea yang terdiri dari 3 spesies yaitu $H$. atra, $H$. scabra dan $H$. leucospilota. Berdasarkan jumlah komposisi, spesies yang paling banyak ditemukan selama pengamatan adalah $H$. scabra sebesar $2,13 \mathrm{ind} / \mathrm{m}^{2}$. Selanjutnya $H$. leucospilota sebesar $2.09 \mathrm{ind} / \mathrm{m}^{2}$, dan yang paling sedikit ditemukan adalah $H$. atra sebesar $1,67 \mathrm{ind} / \mathrm{m}^{2}$ dari total keseluruhan spesies yang di temukan. Pada Pantai Pailus tidak ditemukan Ophiuroidae maupun Echinoidea seperti yang terdapat pada Pantai Krakal. 
Komposisi Echinodermata secara keseluruhan selama penelitian dikedua Pantai yaitu Pantai Krakal dan Pantai Pailus sangat bervariasi antar lokasi penelitian. Kelas Ophiuroidea dan Echinoidea sangat banyak ditemukan pada Pantai Krakal dan Kelas Holothuridea dapat ditemukan di Pantai Pailus. Yusron (2010) menyebutkan bahwa Kelas Ophiuroidea dan Kelas Echinodea pada umumnya ditemukan di daerah rataan terumbu karang. Kedua Kelas ini banyak ditemukan di rataan karang sebagai tempat bersembunyi dan mencari makan di dalam batuan. Aziz (1996) menambahkan bahwa Kelas Ophiuroidea dan Kelas Echinodea bersembunyi di rataan karang untuk menghindari kekeringan saat surut dan sinar matahari. Sedangkan pada Holothuridea menurut Yusron (2010) hewan ini banyak terdapat di rataan terumbu karang, pantai berbatu atau yang berlumpur, dasar perairan berpasir dengan kecerahan yang tinggi, rumput laut dan lamun. Namun, Holothuridea menempati habitat yang selalu tergenang air bahkan saat surut, dan untuk hidupnya, hewan ini lebih menyukai habitat perairan jernih dan relatif tenang (Aziz, 1996).

Kondisi substrat pada Pantai Krakal yang terdiri dari beting karang tidak memungkinkan bagi Holothuria untuk melindungi diri, selain itu, dalam keadaan surut,daerah pantai pada Pantai Krakal tidak tergenang air sehingga tidak memenuhi kelayakan habitat bagi Holothuridea. Ophiuroidea dan Echinoidea merupakan Kelas dari Echinodermata yang memiliki kecenderungan untuk melekat pada karang menurut Sugiarto dan Supardi (1995), selain itu Bulu Babi menyukai dasar substrat yang keras dan substrat di padang lamun campuran yang terdiri dari pasir dan pecahan karang. Kelas Ophiuroidea dan Echinodea memiliki kemampuan mencengkram bebatuan dan dapat menahan diri dari ombak sehingga sanggup beradaptasi di daerah karang (Aziz, 1996).

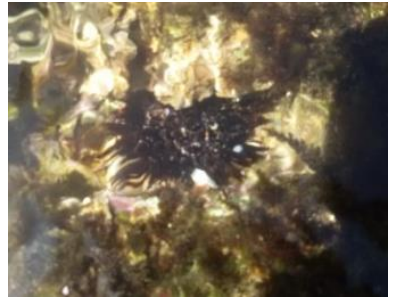

Echinometra viridis
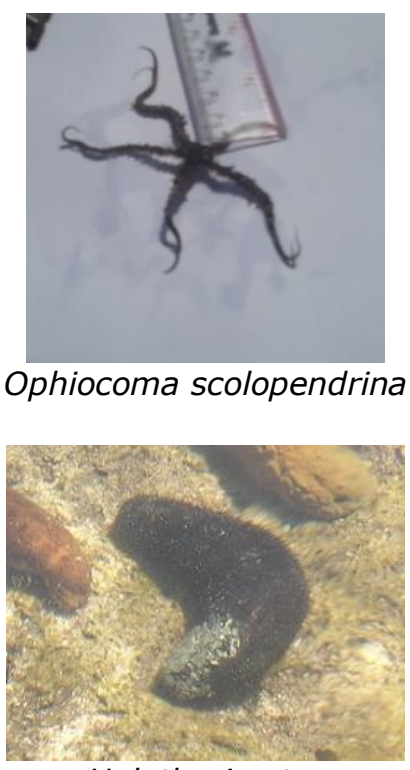

Holothuria atra

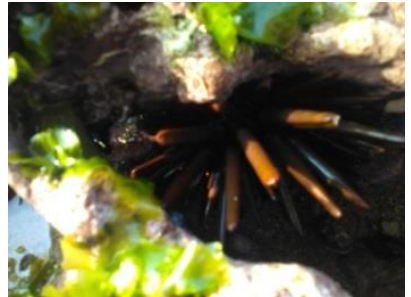

Echinometra oblonga

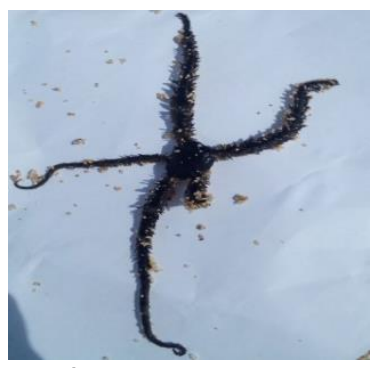

Ophiocoma erinaceus

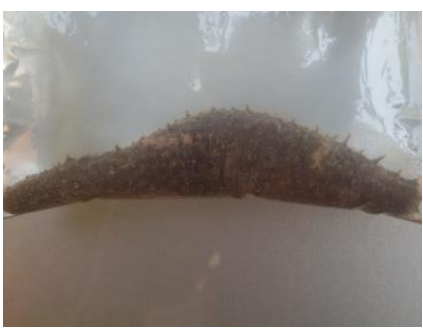

Holothuria leucospilota

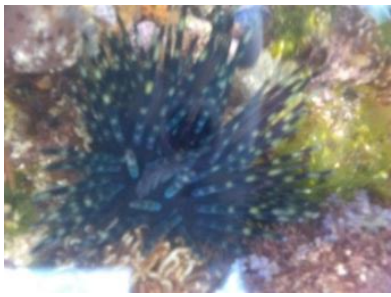

Stomopneutes variolaris

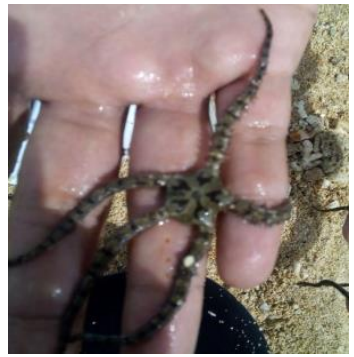

Ophiarachna affinis

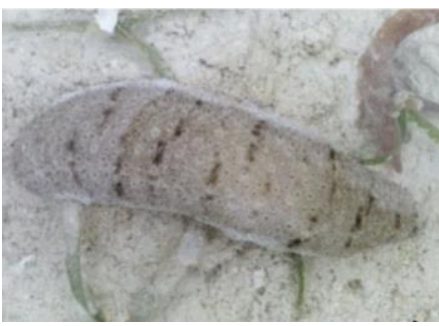

Holothuria scabra

Gambar 4. Spesies Echinodermatayang di temukan 


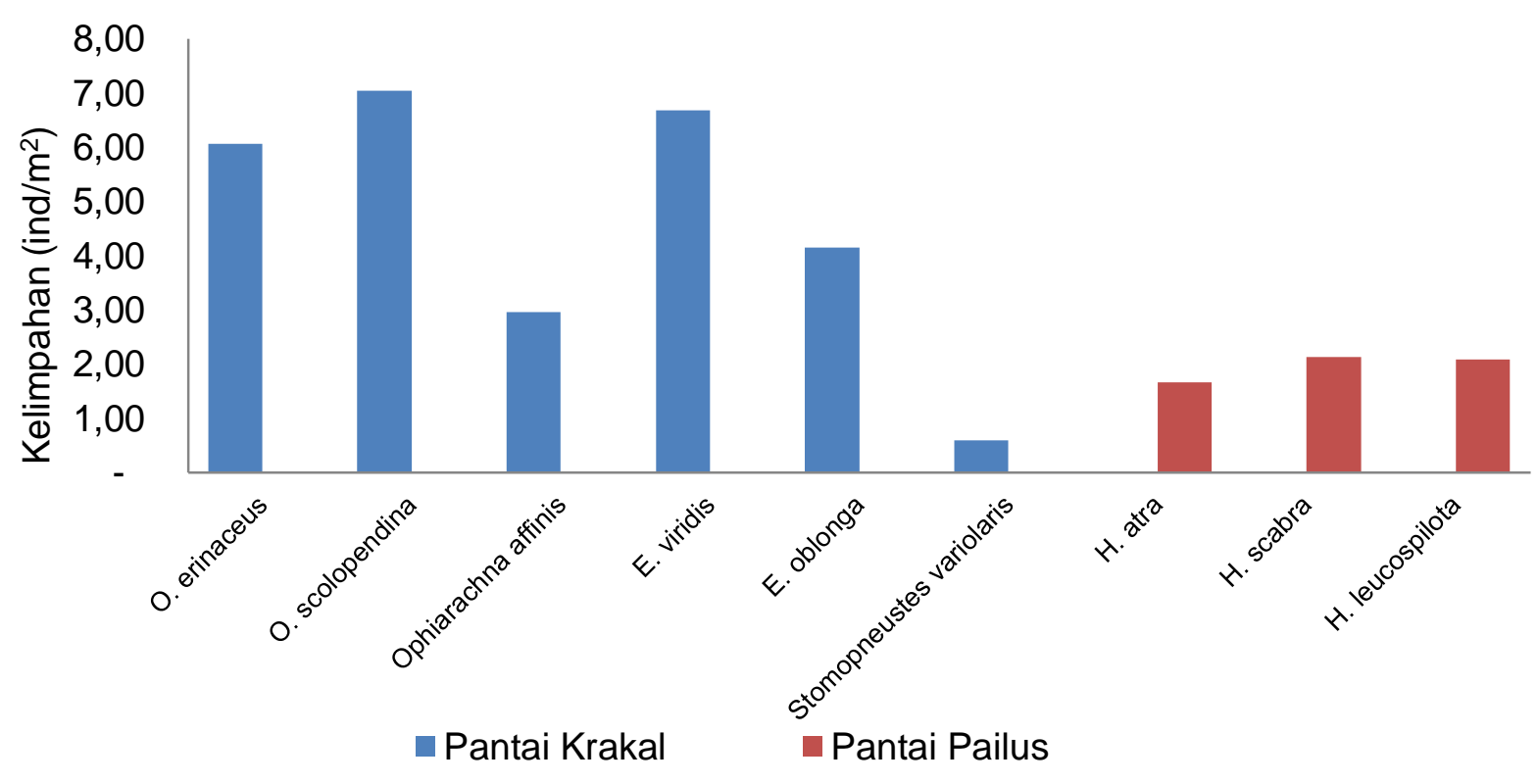

Gambar 5. Rata-rata Kelimpahan jenis (ind $/ \mathrm{m}^{2}$ ) Spesies Echinodermata di Pantai Krakal dan Pantai Pailus

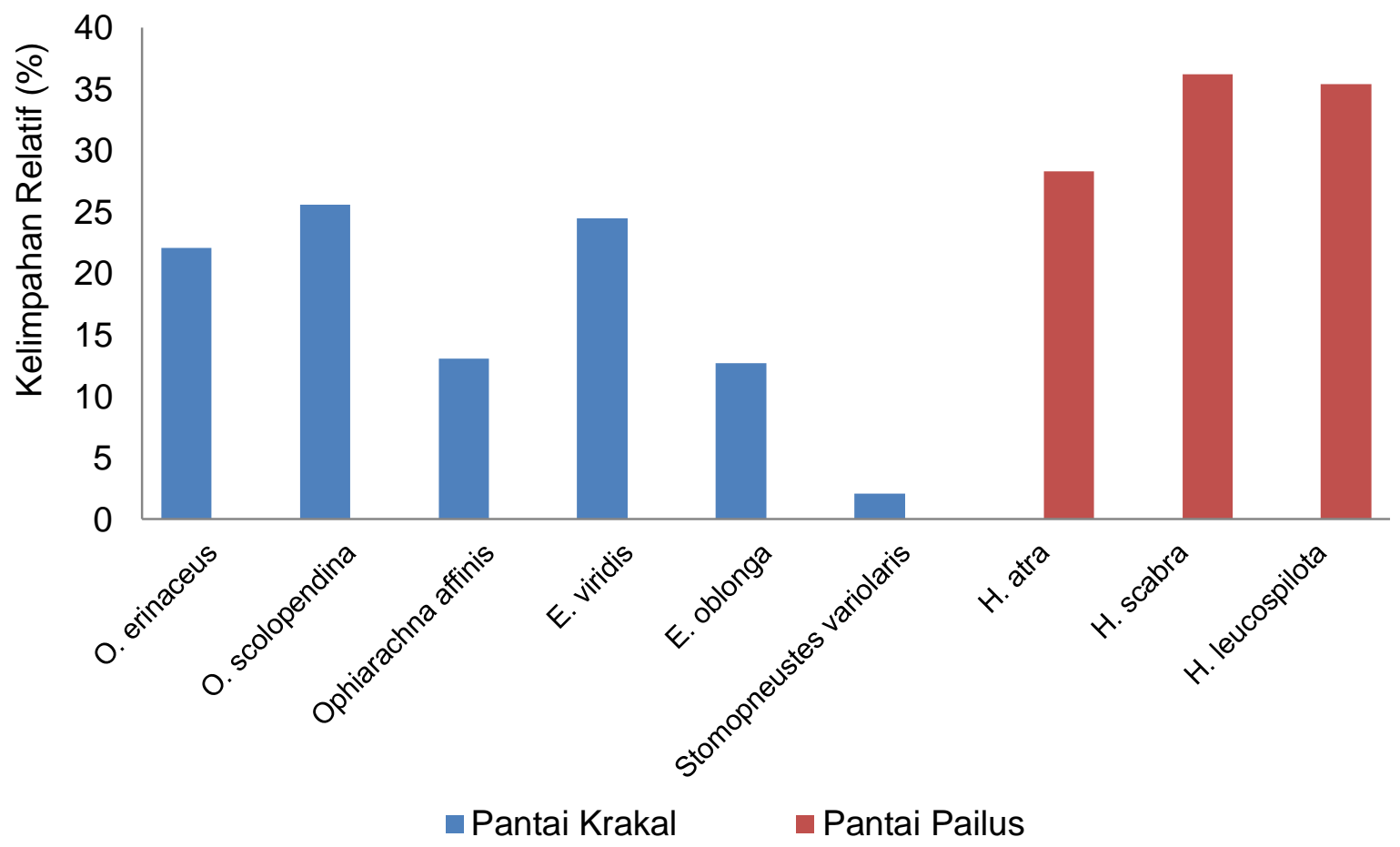

Gambar 6. Rata-rata Kelimpahan Relatif (\%) Spesies Echinodermata di Pantai Krakal dan Pantai Pailus.

\section{Indeks Keanekaragaman, Indeks Keseragaman dan Indeks Dominansi}

Pola Indeks ekologi pada Pantai Krakal menunjukkan bahwa waktu pengamatan umumnya memiliki indeks keanekaragaman rata-rata dengan kategori sedang $(1,38)$, indeks keseragaman rata-rata dengan kategori yang tinggi $(0,83)$ dan secara umum nilai indeks dominansi rata-rata tidak ada dominansi 0,29). Pola Indeks ekologi pada Pantai Pailus menunjukkan bahwa waktu pengamatan umumnya memiliki indeks keanekaragaman rata-rata dengan kategori rendah $(0,9)$, indeks keseragaman rata-rata dengan kategori yang tinggi $(0,87)$ dan secara umum nilai indeks dominansi rata-rata tidak ada dominansi 0,44 ). 
Krebs (1985), menjelaskan bahwa indeks keanekaragaman dapat digunakan untuk menyatakan hubungan kelimpahan spesies dalam suatu komunitas. Keanekaragaman spesies terdiri dari jumlah spesies dalam komunitas. Kesamaan menunjukkan bagaimana kelimpahan spesies itu (jumlah individu ataupun biomassa) yang tersebar di antara banyaknya spesies.

Hasil pengamatan menunjukkan bahwa secara keseluruhan indeks similaritas dalam periode pengamatan hampir sama antar stasiunnya. Hal ini karena faktor ekologis dan faktor fisik kimia yang hampir sama antara setiap stasiun sehingga terdapatnya kesamaan nilai similaritas antar stasiun.

Nilai Indeks Keseragaman (e) pada setiap stasiun berdasarkan indeks Odum (1971) bila 0,4 maka dalam kondisi tertekan, antara 0,4 sampai 0,6 pada kondisi kurang stabil, dan lebih dari 0,6 dalam kondisi stabil. Nilai Indeks Dominansi (D) pada setiap stasiun berdasarkan indeks Simpson (1949) Bila nilai D mendekati nol, tidak terdapat spesies yang mendominasi spesies lain. Bila nilai D mendekati 1, dijumpai spesies yang mendominasi spesies lain.

Tabel 2. Nilai dan Kategori Indeks Keanekaragaman (H'), Indeks Keseragaman (E) dan Indeks Dominansi (C) Pantai Krakal, Gunung Kidul, Yogyakarta.

\begin{tabular}{cccccccc}
\hline Stasiun & Titik & $\mathbf{H}^{\prime}$ & Kategori $^{*}$ & $\mathbf{E}$ & Kategori $^{* *}$ & D & Kategori $^{* * *}$ \\
\hline \multirow{2}{*}{1} & 1 & 1.44 & Sedang & 0.80 & Stabil & 0.29 & TAD \\
& 2 & 1.08 & Sedang & 0.78 & Stabil & 0.39 & TAD \\
& 3 & 1.30 & Sedang & 0.81 & Stabil & 0.33 & TAD \\
\multirow{2}{*}{2} & 1 & 1.57 & Sedang & 0.87 & Stabil & 0.24 & TAD \\
& 2 & 1.44 & Sedang & 0.89 & Stabil & 0.27 & TAD \\
& 3 & 1.48 & Sedang & 0.82 & Stabil & 0.27 & TAD \\
\multirow{2}{*}{3} & 1 & 1.10 & Sedang & 0.68 & Stabil & 0.42 & TAD \\
& 2 & 1.37 & Sedang & 0.85 & Stabil & 0.29 & TAD \\
& 3 & 1.14 & Sedang & 0.70 & Stabil & 0.38 & TAD \\
\multirow{3}{*}{4} & 1 & 1.67 & Sedang & 0.93 & Stabil & 0.20 & TAD \\
& 2 & 1.40 & Sedang & 0.87 & Stabil & 0.25 & TAD \\
& 3 & 1.30 & Sedang & 0.81 & Stabil & 0.32 & TAD \\
& 1 & 1.54 & Sedang & 0.86 & Stabil & 0.25 & TAD \\
5 & 2 & 1.46 & Sedang & 0.90 & Stabil & 0.26 & TAD \\
& 3 & 1.40 & Sedang & 0.87 & Stabil & 0.29 & TAD \\
\hline
\end{tabular}

Keterangan : AD : Ada dominansi TAD : Tidak ada dominansi *: Shannon-Wienner (1963) **: Odum (1971) ${ }^{* * *}:$ Simpson(1949)

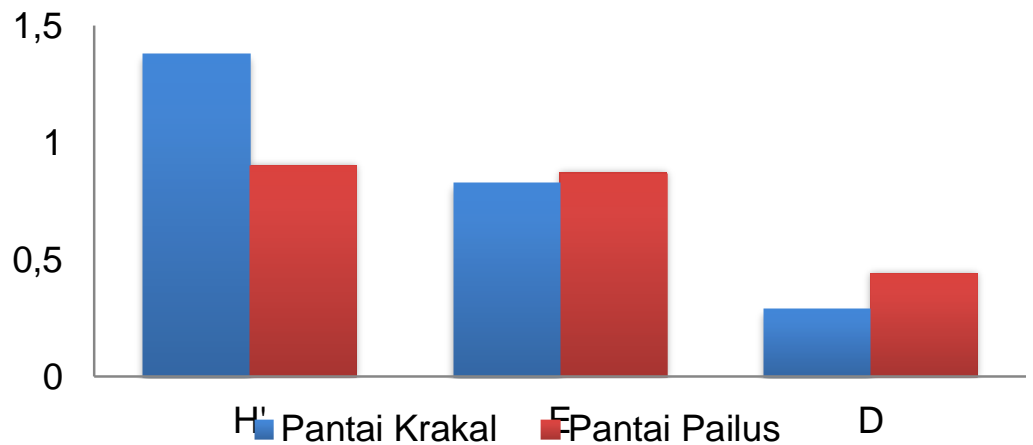

Gambar 7.Nilai dan Kategori Indeks Keanekaragaman $\left(\mathrm{H}^{\prime}\right)$, Indeks Keseragaman $(\mathrm{E})$ dan Indeks Dominansi (D) Pantai Krakal dan Pantai Pailus 
Tabel 3. Nilai dan Kategori Indeks Keanekaragaman (H'), Indeks Keseragaman (E) dan Indeks Dominansi (C) Pantai Pailus, Jepara, Jawa Tengah

\begin{tabular}{|c|c|c|c|c|c|c|c|}
\hline Stasium & Titik & $\mathbf{H}^{\prime}$ & Kategori ${ }^{*}$ & $\mathbf{E}$ & Kategori** & D & Kategori $^{* *}$ \\
\hline \multirow{4}{*}{1} & 1 & 1.09 & Sedang & 0.99 & Stabil & 0.33 & $\mathrm{TAD}$ \\
\hline & 2 & 1.01 & Sedang & 0.92 & Stabil & 0.38 & $\mathrm{TAD}$ \\
\hline & 3 & 0.92 & Rendah & 0.84 & Stabil & 0.43 & $\mathrm{TAD}$ \\
\hline & 1 & 0.90 & Rendah & 0.82 & Stabil & 0.46 & $\mathrm{TAD}$ \\
\hline \multirow[t]{3}{*}{2} & 2 & 1.01 & Sedang & 0.92 & Stabil & 0.38 & $\mathrm{TAD}$ \\
\hline & 3 & 0.9 & Rendah & 0.855 & Stabil & 0.44 & $\mathrm{TAD}$ \\
\hline & 1 & 0.8 & Rendah & 0.80 & Stabil & 0.48 & $\mathrm{TAD}$ \\
\hline \multirow[t]{3}{*}{3} & 2 & 0.96 & Rendah & 0.87 & Stabil & 0.40 & $\mathrm{TAD}$ \\
\hline & 3 & 1.06 & Sedang & 0.97 & Stabil & 0.35 & $\mathrm{TAD}$ \\
\hline & 1 & 0.90 & Rendah & 0.82 & Stabil & 0.44 & $\mathrm{TAD}$ \\
\hline \multirow[t]{3}{*}{4} & 2 & 0.95 & Rendah & 0.87 & Stabil & 0.43 & $\mathrm{TAD}$ \\
\hline & 3 & 0.99 & Rendah & 0.90 & Stabil & 0.40 & $\mathrm{TAD}$ \\
\hline & 1 & 0.62 & Rendah & 0.57 & Kurang Stabil & 0.66 & $\mathrm{TAD}$ \\
\hline \multirow[t]{2}{*}{5} & 2 & 0.70 & Rendah & 1 & Stabil & 0.50 & $\mathrm{TAD}$ \\
\hline & 3 & 0.63 & Rendah & 0.91 & Stabil & 0.55 & $\mathrm{TAD}$ \\
\hline
\end{tabular}

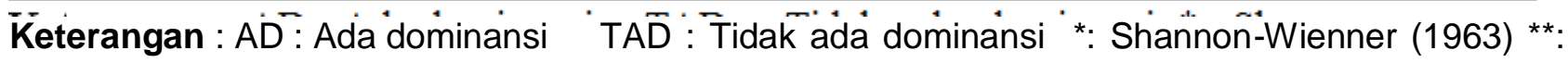
Odum (1971) ${ }^{* * *}$ : Simpson(1949)

\section{Pola Sebaran Echinodermata Pantai Krakal dan Pantai Pailus}

Pola sebaran merupakan pola yang digunakan untuk mengetahui pola sebaran dan persebaran suatu biota laut pada suatu lokasi penelitian. Pola sebaran ditentukan menggunakan kriteria : ID $<1$ adalah pola dispersi seragam (Uniform), ID = 1 adalah pola disperse acak (Random), ID > 1 adalah pola sebaran dispersi mengelompok (Clumped).

Hasil penelitian di Pantai Krakal Pola sebaran Echinodermata pada Pantai Krakal memiliki pola sebaran yaitu clumped dan uniform. Pola sebaran seragam dapat ditemukan pada jenis spesies $O$. erinaceus dan $S$. variolaris. Tidak di temukan pola sebaran acak pada saat pengamatan. Pola sebaran mengelompok dapat ditemukan pada jenis spesies O.erinaceus, $O$. scolopendina, O. affinis, E. viridis, E. oblonga dan S.variolaris kelima spesies tersebut ditemukan di semua stasiun pada Pantai Krakal.

Penelitian pada Pantai Pailus pola sebaran seragam dapat ditemukan pada jenis spesies $H$. atra pada stasiun $2, \mathrm{H}$. leucospilota pada stasiun 4 dan 5 . Pola sebaran mengelompok dapat ditemukan pada jenis spesies $H$. atra, $H$. scabra, dan $H$. leucospilota dan dapat ditemukan pada semua stasiun.

\section{Frekuensi Kehadiran Echinodermata Pantai Krakal dan Pantai Pailus}

Frekuensi kehadiran Echinodermata di Pantai Krakal mempunyai frekuensi yang berbeda beda pada setiap jenis spesies Echinodermata. Spesies $O$. erinaceus mempunyai frekuensi kehadiran sebanyak 100\%, O. scolopendina mempunyai frekuensi kehadiran sebanyak 100\%, $O$. affinis mempunyai frekuensi kehadiran sebanyak $87 \%$, E. viridis mempunyai frekuensi kehadiran sebanyak $100 \%$, E. oblonga mempunyai frekuensi kehadiran sebanyak $93.3 \%$, dan S. variolaris mempunyai frekuensi kehadiran sebanyak $46.47 \%$. 
Frekuensi kehadiran Echinodermata di Pantai Pailus mempunyai frekuensi yang hampir sama pada setiap jenis spesies Echinodermata yang terdapat pada pantai Pailus. Spesies $H$. atra mempunyai frekuensi kehadiran sebanyak 93\%, $H$. scabra mempunyai frekuensi kehadiran sebanyak $93.33 \%$, H. leucospilota mempunyai frekuensi kehadiran sebanyak $100 \%$.

\section{Indeks Kesamaan Komunitas Pantai Krakal dan Pantai Pailus}

Indeks kesamaan komunitas merupakan perhitungan yang digunakan untuk mengetahui tingkat kemiripan komunitas pada suatu lokasi penelitian. Kriteria tingkat kemiripan didasarkan bila IS : $76-100 \%$ (sangat mirip), IS : $51-75 \%$ (mirip), IS : $26-50 \%$ (tidak mirip), IS : <25\% (sangat tidak mirip).

Hasil dari penelitian menunjukkan bahwa Pantai Krakal memiliki kesamaan komunitas yang sangat mirip karena memiliki presentasi lebih dari $70 \%$. Penelitian Pantai Pailus memiliki indeks kesamaan komunitas tertinggi pada semua stasiun yaitu 100\% (sangat mirip). Hal ini menunjukkan bahwa Pantai Pailus memiliki kesamaan komunitas yang sangat mirip.

\section{Parameter Lingkungan Pantai Krakal dan Pantai Pailus, Jepara, Jawa Tengah}

Pengukuran parameter perairan pada kedua pantai pada penelitian ini berada pada kisaran normal, berdasarkan besaran nilai suhu air tersebut menunjukkan bahwa perairan di lokasi penelitian masih dalam kisaran normal pada perairan tropis. Hal ini didukung oleh pernyataan Romimohtarto dan Juwana (2007), bahwa suhu alami air laut berkisar antara $0^{\circ} \mathrm{C}-33^{\circ} \mathrm{C}$ dan perubahan suhu dapat memberi pengaruh besar terhadap sifat-sifat air laut dan termasuk biota laut.

Nilai kisaran $\mathrm{pH}$ pada penelitian masih tergolong baik untuk parameter air laut. Hal ini didukung oleh pernyataan Romimohtarto dan Juwana (2007) dimana pH air laut di Indonesia bervariasi antara 6,0-8,5.

Tabel 3.Pola Sebaran Echinodermata di Pantai Krakal Gunung Kidul Yogyakarta

\begin{tabular}{llllll}
\hline & \multicolumn{5}{c}{ Pola Sebaran (Stasiun) } \\
\cline { 2 - 6 } \multicolumn{1}{c}{ Spesies } & $\mathbf{1}$ & $\mathbf{2}$ & $\mathbf{3}$ & $\mathbf{4}$ & $\mathbf{5}$ \\
\hline Ophiocoma erinaceus & $\mathrm{C}$ & $\mathrm{C}$ & $\mathrm{C}$ & $\mathrm{C}$ & $\mathrm{U}$ \\
Ophiocoma scolopendina & $\mathrm{C}$ & $\mathrm{C}$ & $\mathrm{C}$ & $\mathrm{C}$ & $\mathrm{C}$ \\
Ephiarachna affinis & $\mathrm{C}$ & $\mathrm{C}$ & $\mathrm{C}$ & $\mathrm{C}$ & $\mathrm{C}$ \\
Echinometra viridis & $\mathrm{C}$ & $\mathrm{C}$ & $\mathrm{C}$ & $\mathrm{C}$ & $\mathrm{C}$ \\
Echinometra oblonga & $\mathrm{C}$ & $\mathrm{C}$ & $\mathrm{C}$ & $\mathrm{C}$ & $\mathrm{C}$ \\
Stomopneustes variolaris & $\mathrm{U}$ & $\mathrm{C}$ & & $\mathrm{C}$ & $\mathrm{C}$ \\
\hline
\end{tabular}

Tabel 4. Pola Sebaran Echinodermata di Pantai Pailus Jepara Yogyakarta

\begin{tabular}{llllll}
\hline & \multicolumn{5}{c}{ Pola Sebaran (Stasiun) } \\
\cline { 2 - 7 } \multicolumn{1}{c}{ Spesies } & $\mathbf{1}$ & $\mathbf{2}$ & $\mathbf{3}$ & $\mathbf{4}$ & $\mathbf{5}$ \\
\hline HolothuriaAtra & $\mathrm{C}$ & $\mathrm{C}$ & $\mathrm{C}$ & $\mathrm{C}$ & $\mathrm{C}$ \\
HolothuriaScabra & $\mathrm{C}$ & $\mathrm{C}$ & $\mathrm{C}$ & $\mathrm{C}$ & $\mathrm{C}$ \\
HolothuriaLeucospilota & $\mathrm{C}$ & $\mathrm{C}$ & $\mathrm{U}$ & $\mathrm{C}$ & $\mathrm{C}$ \\
\hline-
\end{tabular}

Tabel 5.Indeks Kesamaan Komunitas Pantai Krakal Gunung Kidul Yogyakarta 


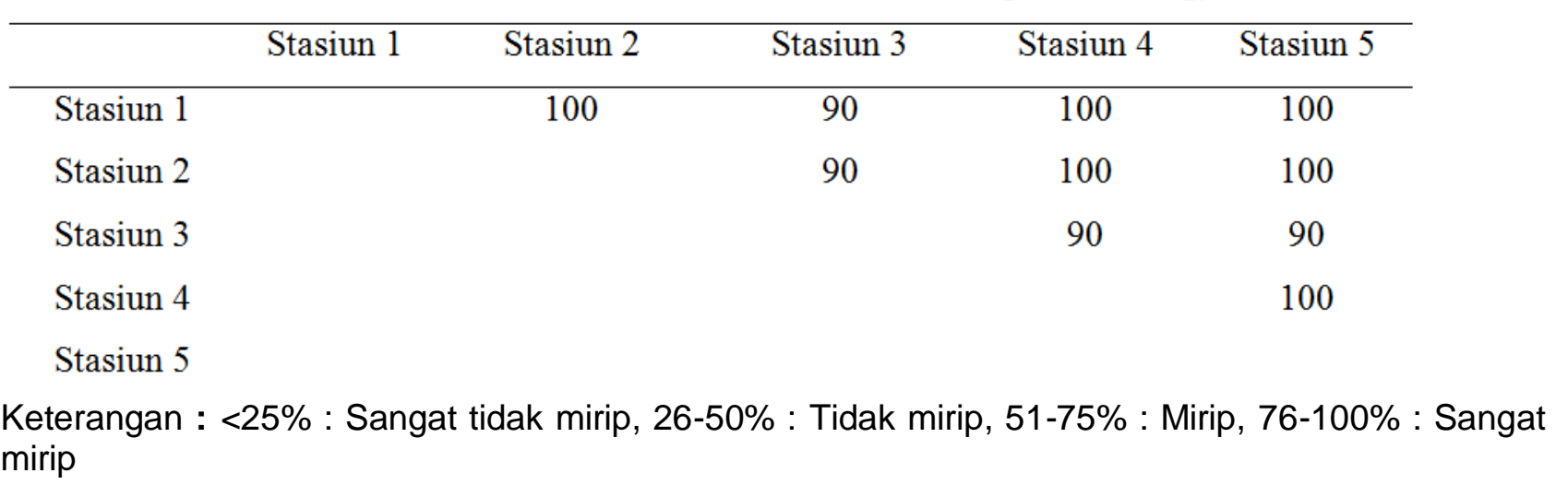

Tabel 6.Indeks Kesamaan Komunitas Pantai Pailus Jepara Jawa Tengah

\begin{tabular}{lccccc} 
& Stasiun 1 & Stasiun 2 & Stasiun 3 & Stasiun 4 & Stasiun 5 \\
\hline Stasiun 1 & 100 & 100 & 100 & 100 \\
Stasiun 2 & & & 100 & 100 & 100 \\
Stasiun 3 & & & 100 & 100 \\
Stasiun 4 & & & & 100 \\
Stasiun 5 & & & & \\
\hline
\end{tabular}

Keterangan : $<25 \%$ : Sangat tidak mirip, $26-50 \%$ : Tidak mirip, $51-75 \%$ : Mirip, $76-100 \%$ : Sangat mirip

Tabel 7. Nilai Parameter Lingkungan Pantai Krakal dan Pantai Pailus

\begin{tabular}{llll}
\hline $\begin{array}{l}\text { Parameter } \\
\text { Lingkungan }\end{array}$ & Pantai Krakal & Pantai Pailus & Kelayakan \\
\hline Suhu air $\left({ }^{\circ} \mathrm{C}\right)$ & $28,5-29$ & $29-30,5$ & 28-34 (Azis, 1996) \\
$\mathrm{pH}$ & $8,50-8,55$ & $8,40-8,42$ & $7-8$ (Azis, 1996) \\
Salinitas (\%) & $34,0-34,4$ & $32,3-32,6$ & $30-34 \%$ (Azis, 1987) \\
DO (mg/l) & $4-4,07$ & $8,39-8,64$ & $>2$ ppm \\
Kecerahan $(\mathrm{cm})$ & Sampai dasar & Sampai dasar & Sampai dasar \\
Kedalaman $(\mathrm{cm})$ & $10-27$ & $74-119$ & $0->6500$ m (Sthor, 2012) \\
Substrat & Karang & Pasir & Karangmati, Pecahan karang, \\
& & & dan Pasir (Azis, 1987) \\
\hline
\end{tabular}

Nilai yang didapatkan pada pengukuran salinitas pada stasiun penelitian masih tergolong normal, karena lokasi stasiun penelitian merupakan perairan terbuka dengan Samudera Hindia sebagai batasnya. Menurut Ruswahyuni (2010) Salinitas di perairan terbuka memiliki kisaran 31 37 ppt dengan rata-rata sebesar 35 ppt. Nontji (2002) menambahkan bahwa, Samudera umumnya memilki nilai salintas berkisar antara 34-35 ppt. 
Perairan pada kedua lokasi kajian penelitian ini memiliki perairan yang jernih. Kecerahan pada lokasi penelitian bernilai tak terhingga yang berarti cahaya matahari dapat menembus hingga dasar perairan, serta kedalaman pada lokasi penelitian memliki penetrasi cahaya yang tinggi.

Menurut Romimohtarto dan Juwana (2007) bagi hewan laut, cahaya mempunyai pengaruh besar namun secara tidak langsung, yakni sebagai sumber energi untuk proses fotosintesis tumbuh-tumbuhan yang menjadi sumber makanan serta penyedia oksigen bagi mereka.

Substrat secara keseluruhan pada Pantai Krakal sebagai lokasi penelitian merupakan beting karang yaitu terdiri dari bongkah karang (boulders) dan pecahan karang (rubbles) yang berada pada perairan pantai. Berbeda dengan substrat pada Pantai Pailus yang berupa pasir. Perbedaan substrat ini menyebabkan perbedaan jenis Echinodermata yang dapat di temukan pada kedua pantai tersebut.

\section{KESIMPULAN}

Jumlah jenis Echinodermata yang ditemukan di Pantai Krakal terdiri dari 6 spesies, yaitu $O$. erinaceus, O. scolopendrina, Ophiarachna affinis, E. viridis, E. oblonga, dan Stomopneustes variolaris. Sedangkan jenis Echinodermata yang ditemukan di Pantai Pailus terdiri dari 3 spesies, yaitu $H$. atra, $H$. scabra, dan $H$. leucospilota. Jenis Echinodermata yang ditemui paling banyak di Pantai Krakal adalah O. scolopendrina dengan nilai $7.05 \mathrm{ind} / \mathrm{m}^{2}$ dari total jumlah individu yang ditemukan, sedangkan jenis Echinodermata yang ditemui paling banyak di Pantai Pailus adalah Holothuria scabra dengan nilai $2.13 \mathrm{ind} / \mathrm{m}^{2}$ dari total jumlah individu yang ditemukan

\section{DAFTAR PUSTAKA}

Aziz. 1996. Habitat dan zonasi fauna Echinodermata di ekosistem terumbu karang. Oseana, 21(2):33-43.

Bird, E.C.F. \& Ongkosongo, O.S.R. 1980). Environmental Changes on the Coasts of Indonesia. The United Nation University, Tokyo: $52 \mathrm{pp}$.

Dahuri, R. 2003. Keanekargamaan Hayati Laut Aset Pembangunan Berkelanjutan Indonesia. PT Gramedia Pustaka Utama. Jakarta : 412p.

Darsono, P. 2007. Teripang (Holothuridea) Kekayaan Alam Dalam Keragaman Biota Laut. Oseana, 32(2):1-10.

English, Wilkinson, S.C. \& Baker, V. 1994. Survey Manual for Torpical Marine Resources. Australian Institute of Marine Scince. Townville: 368p.

Fachrul, M.F. 2007. Metode Sampling Bioekologi. Bumi Aksara. Jakarta : $198 \mathrm{hlm}$.

Feryanto, O., Hartati, R. \& Pringgenies, D. 2015. Identifikasi Teripang Holothuria atra dengan menganalisanya berdasarkan morfologi, anatomi dan tipe spikula. Project Report. Program Studi IImu Kelautan Universitas Diponegoro.

Kluijver, M., Gijswijt, G., de Leon, R., \& Da Cunda. 2016. Marine Species Identification Portal. Interactive Guide to Caribbean Diving.

Krebs, C.J. 1985. Ecology: The Experimental Analysis of Distribution and Abundance. Third Edition. Harper and Row, New York. 800 pp.

Müller, J. \& Troschel, F.H. 1842. System der Asteriden. Braunschweig, 134 p.

Nontji, A. 2002. Laut Nusantara - cet. 3. Jakarta: Djambatan, 351 hlm.

Odum, E.P. 1971. Fundamentals of Ecology.Third Edition. W. B. Sounders Company. Philadelphia, London, Toronto. Toppan Company, Ltd. Tokyo, Japan, 574 p.

Odum, E.P. 1993. Dasar-dasar Ekologi. Terjemahan Tjahjono Samingan. Edisi Ketiga. Yogyakarta: Gadjah Mada University Press. 679 hlm.

Romimohtarto, K. \& Juwana, S. 2007. Biologi Laut: Ilmu Pengetahuan tentang Biota Laut. Jakarta: Djambatan: $540 \mathrm{p}$.

Ruswahyuni. 2010. Populasi dan Keanekaragaman Hewan Makrobenthos pada Perairan Tertutup dan Terbuka di Teluk Awur, Jepara. Jurnal IImiah Perikanan dan Kelautan. 2(1):11-20.

Shannon, C.E. \& Wiener, W. 1963. The Mathematical Theory of Communication. University Illinois Press, Urbana, $360 \mathrm{p}$. 
Simpson, E.H. 1949 Measurement of diversity. Nature, 163, 688.

Sloan N. A., Clark, A. M. \& Taylor, J. D. 1979. The Echinoderms of Aldabra and Their Habitats. Bulletin of the British Museum (Natural History). Zoology 37(2):81-128.

Sugiarto, H. dan Supardi 1995. Beberapa catatan tentang bulu babi marga Diadema. Oseana 20(4): 35.

Yusron, E. 2010. Keanekaragaman Species Ekhinodermata di Perairan Likupang, Minahasa Utara, Sulawesi Utara. IImu Kelautan : Indonesian Journal of Marine Sciences. 15 (2):85-90. 